\title{
Assessment of Undiscovered Oil and Gas Resources of the Wyoming Thrust Belt Province, 2003
}

Sing a geology-based assess-
ment methodology, the U.S. Geological Survey estimated a mean of 918 billion cubic feet of undiscovered natural gas, a mean of 39 million barrels of undiscovered oil, and a mean of 57.3 million barrels of undiscovered natural gas liquids in the Wyoming Thrust Belt Province.

\section{Introduction}

The U.S. Geological Survey (USGS) recently completed an assessment of the undiscovered oil and gas potential of the Wyoming Thrust Belt Province (fig. 1). The province includes all the major thrusts faults within those parts of Idaho, Utah, and Wyoming bounded on the northwest by the Snake River Plain, on the east by the Greater Green River Basin, on the south by the Uinta Mountains and associated structures, and on the west by the easternmost major extensional fault of the Basin and Range Province (fig. 1). The assessment is based on the identification and integration of geologic elements, including hydrocarbon source rocks (source-rock maturation, hydrocarbon generation, and migration), reservoir rocks (sequence stratigraphy and petrophysical properties), and hydrocarbon traps (trap formation and timing). By using this geologic framework, the USGS defined two Total Petroleum Systems (TPS), each containing one Assessment Unit (AU), as follows: (1) ): Mowry Composite TPS and Thrust Belt Conventional AU (fig. 2); and (2) Frontier-Adaville-Evanton Coalbed Gas TPS and Frontier-Adaville-Evanton Coalbed Gas AU (fig. 3). Quantitative estimates of the undiscovered oil and gas resources in each of the AUs are listed in table 1.

\section{Petroleum Systems}

The Mowry Composite TPS is defined as a composite system because, although the source is dominated by the Cretaceous Mowry Shale and the correlative Aspen Shale, it also may have contributions from organic-rich beds in the Cretaceous Bear River and Frontier Formations and possibly minor contributions from the Permian Phosphoria Formation. The Frontier-Adaville-Evanston Coalbed Gas TPS is a hypothetical petroleum system consisting of Cretaceous and Tertiary strata preserved in narrow elongate synclines parallel to the trend of the major thrust faults. The main coalfields (fig. 3) having coalbed methane poten- tial include the Coalville and Hams Fork coalfields in Utah, and the Evanston, Kemmerer, Greys River, and McDougal coalfields in Wyoming.

\section{Resource Summary}

The USGS assessed undiscovered conventional oil and gas and undiscovered continuous (unconventional) gas in the two TPSs, resulting in estimated means of 918 billion cubic feet (BCF) of undiscovered natural gas, 39 million barrels (MMBO) of undiscovered oil, and 57.3 million barrels of undiscovered natural gas liquids (MMBNGL) (table 1). About 61 percent of the gas (557 BCF) and all of the oil (39 MMBO) and natural

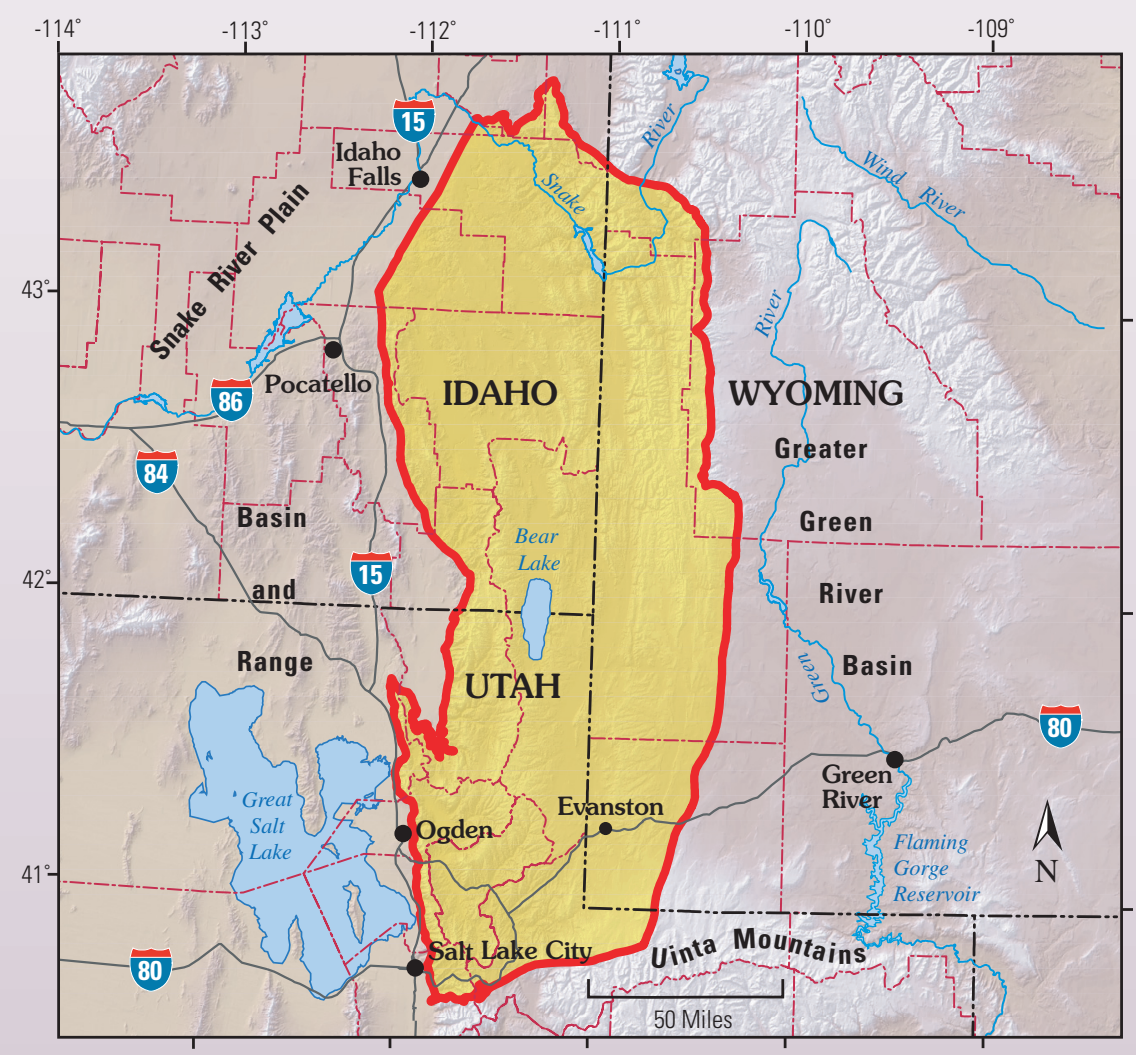

Figure 1. Wyoming Thrust Belt Province of southeastern Idaho, northwestern Utah, and western Wyoming. 


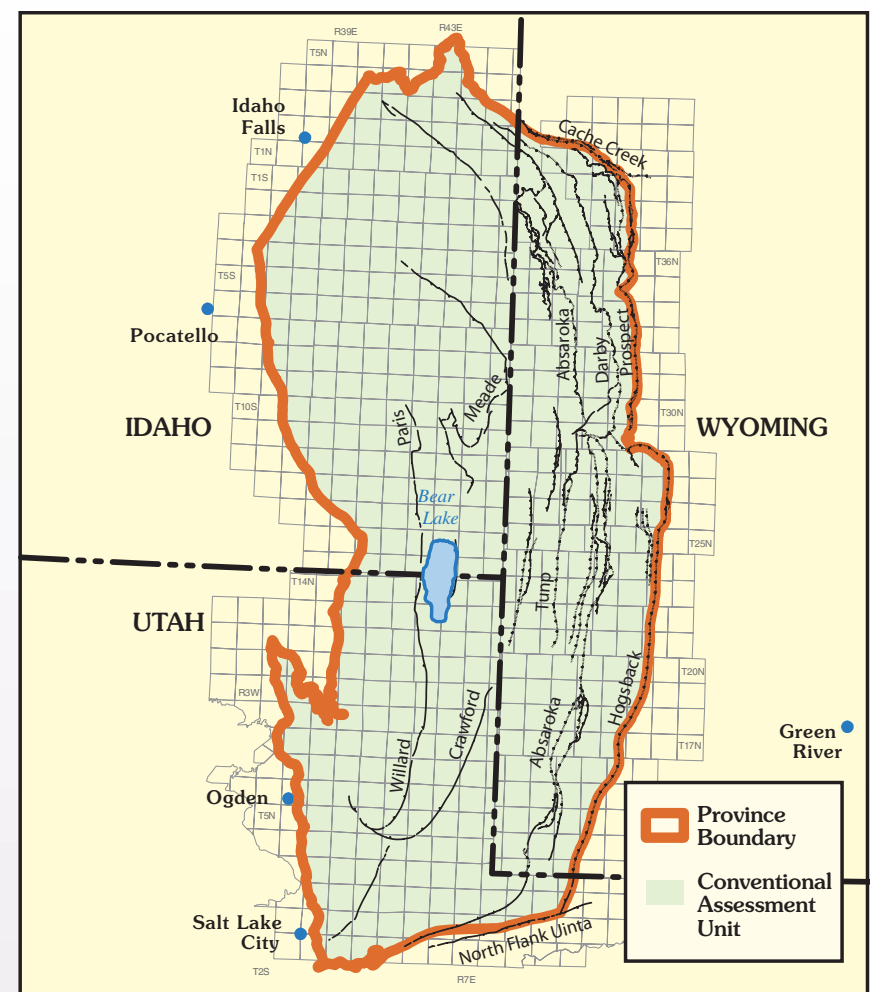

Figure 2. Thrust Belt Conventional Assessment Unit and major thrust faults within the Wyoming Thrust Belt Province. The assessment unit area is the same as the extent of the Mowry Composite Total Petroleum System boundary.

gas liquids (57.3 MMBNGL) are contained within the Mowry Composite TPS and its single AU. The remaining 39 percent of the gas resource is continuous and contained within the Frontier-AdavilleEvanston Coalbed Gas TPS and AU.

\section{For Additional Information}

Supporting geologic studies of Total Petroleum Systems and Assessment Units and a report on the methodology used in the Wyoming Thrust Belt Province assessment are in progress. Assessment results are available at the USGS Central Energy Team website: http://energy.cr.usgs.gov/oilgas/noga/

\section{Wyoming Thrust Belt Province Assessment Team:}

Mark A. Kirschbaum (Task Leader; mkirsch@usgs.gov), Ronald R. Charpentier, Robert A. Crovelli, Timothy R. Klett, Richard M. Pollastro, and Christopher J. Schenk.

Table 1. Wyoming Thrust Belt assessment results.

[MMBO, million barrels of oil. BCFG, billion cubic feet of gas. MMBNGL, million barrels of natural gas liquids. Results shown are fully risked estimates. For gas fields, all liquids are included under the NGL (natural gas liquids) category. Undiscovered gas resources are the sum of nonassociated and associated gas. F95 represents a 95 percent chance of at least the amount tabulated. Other fractiles are defined similarly. Fractiles are additive under the assumption of perfect positive correlation. Gray shading indicates not applicable. CBG is coalbed gas.]

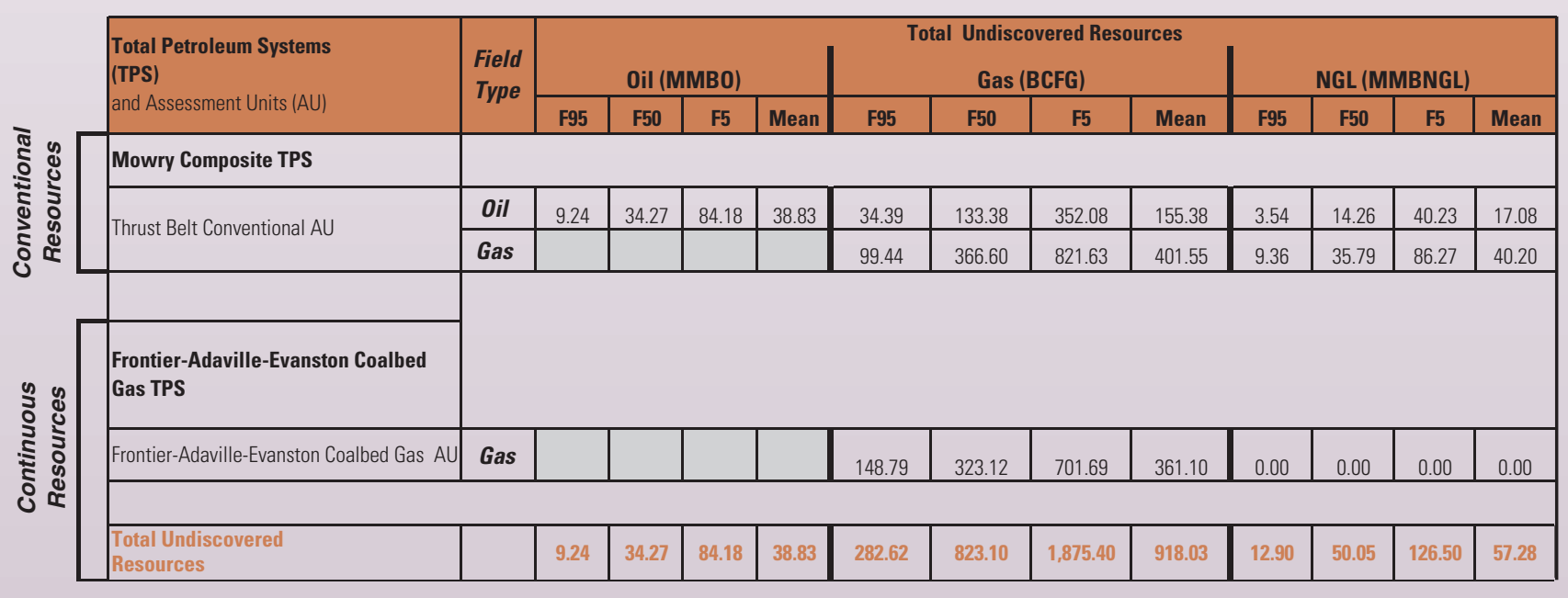

